\title{
The Tainted Muse
}


This page intentionally left blank 


\title{
The Tainted Muse
}

Prejudice and Presumption in Shakespeare and His Time

\author{
Robert Brustein
}

Yale University Press New Haven and London 
Published with assistance from the foundation established in memory of Philip Hamilton McMillan of the Class of 1894 , Yale College.

Copyright (C) 2009 by Robert Brustein.

All rights reserved.

This book may not be reproduced, in whole or in part, including illustrations, in any form (beyond that copying permitted by Sections Io7 and 108 of the U.S. Copyright Law and except by reviewers for the public press), without written permission from the publishers.

Set in Electra Roman types by Tseng Information Systems, Inc. Durham, North Carolina.

Printed in the United States of America by Sheridan Books, Ann Arbor, Michigan.

Library of Congress Cataloging-in-Publication Data Brustein, Robert Sanford, 1927-

The tainted muse : prejudice and presumption in Shakespeare and his time / Robert Brustein.

p. $\mathrm{cm}$.

Includes bibliographical references and index.

IS BN 978-0-300-II576-5 (cloth : alk. paper) I. Shakespeare, William, I564-I6I6-Characters. 2. Prejudices in literature. 3. Misogyny in literature. 4. Stereotypes (Social psychology) in literature. 5. Characters and characteristics in literature. I. Title. II. Title: Prejudice and presumption in Shakespeare and his time.

$$
\begin{gathered}
\text { PR2 2989. B7 } 2009 \\
822.3 \text { ' } 3-\text { dc22 } \\
2008046997
\end{gathered}
$$

A catalogue record for this book is available from the British Library.

This paper meets the requirements of ANSI/NISO Z39.48-I992 (Permanence of Paper). It contains 30 percent postconsumer waste $(\mathrm{PCW})$ and is certified by the Forest Stewardship Council (FSC).

$$
\text { I0 } \quad 9 \begin{array}{llllllll}
8 & 7 & 6 & 5 & 4 & 3 & 2 & \text { I }
\end{array}
$$


For the students who helped me explore Shakespeare; for the scholars who helped me understand him; for the actors who helped me love him And always for Doreen. 
This page intentionally left blank 